\begin{tabular}{l}
\hline Nuansa Journal of Arts and Design \\
Volume 5 Nomor 1 April 2021 \\
e-ISSN: 2597-405X dan p-ISSN: 2597-4041 \\
\begin{tabular}{|l|l|}
\hline (c) This work is licensed under a Creative Commons Attribution \\
\hline
\end{tabular} 4.0 International License
\end{tabular}

\title{
Bentuk Hiasan pada Kerajinan Logam Mulia Karya Para Perajin Perhiasan Satando Di Kecamatan Wajo Kota Makassar
}

\author{
Muhammad Sanusi \\ Penulis
}

Keywords :

Ragam hias;

Kerajinan logam;

Satando;

\section{Corespondensi Author}

PPs Universitas Negeri Makassar

Email:muh.sanusi1996@gmail.com

\begin{abstract}
ABSTRAK
Penelitian ini bertujuan untuk mengetahui kerajinan yang ada di kelompok Satando dengan melihat bentuk produk kerajinan dan jenis ragam hias yang diterapkan pada kerajinan satando tersebut. Jenis penelitian ini menggunakan metode (survey dan analisis isi). Produk kerajinan kelompok Satando yang akan di teliti adalah produk kerajinan yaitu cincin, gelang, kalung, dan anting-anting subject matternya adalah jenis dan ragam hias. Menurut informasi yang diperoleh oleh penulis, jumlah produk dan ragam hias yang subject matternya ada empat jenis produk dan ragam hias ada dua jenis. Hasil penelitian yaitu: (1) Perkembagan produk pada kerajinan kelompok kerajinan perhiasan Satando dan ragam hias pada kerajinan perhiasan masih mengikuti permintaan konsumen yang dominan kepada ragam hias flora dan geometris (2) Ragam hias yang diterapkan kelompok kerajinan perhiasan Satando Kota Makassar.
\end{abstract}

\section{PENDAHULUAN}

Bangsa Indonesia dikenal sebagai bangsa yang memiliki beraneka ragam kesenian daerah. Tiap daerah memiliki corak dan jenis yang berbeda dengan daerah lain. Pada hakekatnya seni kerajinan Indonesia mencerminkan bermacam macam kebudayaan etnik yang tersebar di seluruh kepulauan Nusantara. Untuk mengenal dan memberikan penilaian karya seni kerajinan diperlukan pengetahuan tentang latar belakang yang antara lain menyangkut kesejahtraan dan kehidupan sosial-budaya Bangsa.

Memasuki era modern ini seni telah memiliki banyak kemajuan dan berbagai macam bentuk aliran, pandangan dan pengertian. Begitu pun dalam seni rupa yang memiliki macam bidang seni termasuk seni lukis, patung, seni grafis, kerajinan, dan lain-lain. Sebuah karya seni yang pembuatannya mengunakan keterampilan tangan manusia yang disebut kerajinan dan biasanya hasil dari kerajinan tersebut menghasilkan sebuah karya seni yang indah. Namun dibalik dari karya seni yang indah memiliki ketekunan, kecekatan, dan berdedikasi yang tinggi bagi pembuatnya.

Sulawesi Selatan khususnya di daerah Makassar terdapat beberapa kelompok perajin perhiasan logam mulia yang salah satunya ada di daerah Kelurahan Malimogan Kecamatan Wajo Kota Makassar. Kelompok Perajin Perhiasan (KPP) Satando, yang dibentuk pada lima Tahun yang lalu atas inisiasi Pemerintah Kota (PEMKOT) melalui Dinas Perindustrian dan Perdagangan Kota Makassar.

KPP Satando memiliki Ketua yang 
bertanggungjawab mengenai kerajianan yang ada di Satando yaitu Bapak H. Haris dan sekaligus sebagai Ketua RT di Satando 3, yang anggotanya itu dari masyarakat tersebut. KPP Satando mengerjakan berbagai jenis kerajinan perhiasan logam mulia emas atau perak dan masing-masing anggota mengerjakan satu jenis kerajinan saja, seperti cincin dan perajinan lain gelang, kalung dan seterusnya. dengan jenis perhiasan dan motif yang diterapkan dalam perhiasan tersebut. Dengan sumber daya manusia yang cukup banyak, pada KPP Satando ini dapat memproduksi kerajinan setiap harinya, seperti cincin, kalung, gelang dan lain-lain untuk diberikan pada pemesan atau dijual di daerah Somba Opu. Oleh karna itu menarik untuk diteliti agar ada kajian analisis ragam hias pada kerajinan logam mulia pada Kelompok Kerajinan Perhiasan Satando di Kecematan Wajo Kota Makassar.

\section{METODE}

Penelitian ini menggunakan jenis penelitian survei dan analisis isi. Penelitian survei digunakan untuk mengetahui produk dan ragam hias produk perhiasan dengan cara observasi, wawancara, dan dokmentasi. Sedangkan analisis isi bertujuan untuk mengetahui gambaran karakteristk isi dan inferensi dari isi.

Penelitian ini berada di Jalan Satando 3, Kelurahan Malimongan, Kecamatan Wajo, Kota Makassar Variabel penelitian yang digunakan memfokuskan pada bentuk bentuk produk perhiasan yaitu karya kerajinan perhiasan yang dikerjakan dari bahan dasar logam mulia dan jenis ragam hias yang digunakan perajin kelompok Satando di daerah Kelurahan Malimongan Kecamatan Wajo Kota Makassar.

Teknik pengumpulan data yang digunakan pada penelitian ini adalah teknik observasi, wawancara dan dokumentasi.

Data yang didapatkan dari hasil wawancara, observasi, dan dokumentasi kemudian dirangkum dan diseleksi dengan menggunakan teknik pengolahan data primer dan data sakunder.
Teknik analisis data dalam penelitian ini menggunakan analisis secara kualitatif dari hasil observasi, wawancara dan dokumentasi.

\section{HASIL DAN PEMBAHASAN}

Hasil penelitian yang diperoleh selama masa penelitian yang melalui metode observasi insturumen dalam pengumpulan data penjawaban rumusan masalah penelitian yang dikemukakan sebagai berikut.

\section{Bentuk Produk Kerajinan Kelompok Satando}

Bentuk produk yang dihasilkan perajin kelompok Satando yang berada di Jalan Satando 3, Kecematan Wajo Kota Makassar. Memiliki berbagai jenis produk-produk yang dihasilkan pada kelompok tersebut, antara lain cincin, kalung, gelang, dan anting. Dengan jumah anggota kelompok perajina Satando, Adapun daftar nama anggota KPP Satando Kecematan Wajo Kota Makassar sebagai berikut:

1. Shidik dengan jenis kerajinan yang dibuat yaitu perhiasan cincin logam mulia berupa emas dengan jenis ragam hias flora.

2. Anwar dengan jenis kerajinan perhiasan yang dibuat yaitu perhiasan kalung liontin bahan emas murni dengan jenis ragam hias geometris.

3. Herman dengan jenis kerajinan perhiasan yang dibuat yaitu perhiasan cincin emas dengan jenis ragam hias flora.

4. Syarifuddin dengan jenis kerajinan perhiasan yang dibuat yaitu perhiasan anting-anting bola dengan jenis ragam hias motif tumbuhan atau ragam hias flora

5. H. Aris dengan jenis kerajinan perhiasan yang dibuat yaitu perhiasan cincin huruf dengan logam mulia emas dengan motif ragam hias geometris

6. H. Hasan dengan jenis kerajinan perhiasan yang dibuat yaitu perhiasan gelang bola permata dengan jenis ragam hias flora aau motif tumbuhan.

7. Atong dengan jenis kerajinan perhiasan yang dibuat yaitu perhiasan kalung liontin emas dengan ragam hias yang digunakan yaitu geometris.

8. Anzar dengan jenis kerajinan perhiasan yang dibuat yaitu perhiasan anting liontin emas dengan ragam hias yang digunakan motif geometris dan flora. 
9. Efenddin dengan jenis kerajinan perhiasan yang dibuat yaitu perhiasan cincin emas dengan ragam hias yang digunakan motif kembang dan ragam hias flora.

10.H. Amir dengan jenis kerajinan perhiasan yang dibuat yaitu perhiasan gelang lidi yang terbuat dari emas dengan ragam hias geometris.

Produk perhiasan yang dikerjakan perajin Satando itu di produksi untuk dijual atau dipasarkan dan juga menerima pesanan dari konsumen baik dalam atau di luar Kota Makassar, biasanya KPP Satando membawa atau mendapat pesanan dari toko emas yang ada di Jalan Somba Opu yang telah menjalin kerjasama sebelumnya. Pengerjaan Produk kerajinan di Satando yang berupa pesanan ini mempunyai standar jumlah atau grosir dan tidak menerima dalam bentuk satuan, pengerjaan kerajinan ini dikerjakan secara tradisioanal dengan keterampilan tangan Sang perajin yang mengunakan alat-alat tradisional yang dimilikinya, dan jumlah sumber daya manusia dikelompok tersebut yang cukup banyak. masing-masing memiliki bagian dalam proses pengerjaan sehingga dapat mengerjakan perhiasan dalam seharinya. Berikut ini adalah penjelasan mengenai produk perhiasan KPP Satando sebagai berikut:

1. Produk Cincin, Perhiasan ini sering kita gunakan, yang memiliki bentuk lingkaran, yang melingkar dijari, yang sering dipakai oleh laki-laki dengan nama cincin batu akik permata.

2. Produk perhiasan Bapak Herman merupakan cincin emas yang merupakan cicin khusus wanita dengan bentuk produk yang simple yang membentuk sebuah huruf inisial nama pemakainya dengan tambahan batu permata. dimana menggunakan alat seperti solder, kikir atau kikkri dan gilingan yang merupakan alat untuk membentuk cincin tersebut

3. Gelang, Tampilan perhiasan yang dinamakan gelang permata bola diproduksi oleh perajin Bapak H. Hasan anggota KPP Santando yang sangat bervariatif ada polos tanpa diberi ornamen dan ada yang diberi ornamen, dengan berbagai motif yang diterapkan di bagian gelang, bahkan tidak jarang dari berbagai motif yang diterapkan tersebut dengan tampilan kombinasi dengan berbagai batu permata, seperti intan, berlian dan batu akiky yang berbentuk bola.

4. Perhiasan gelang lidi yang merupakan hasil dari kerajinan Bapak H. Amir yang merupakan gelang yang menyerupai sehelai lidi yang melengkung yang dibuat khusus untuk gelang anak - anak pada gambar gelang di atas di buat dengan tampilan tanpa ornamen tambahan seperti batu permata melainkan dengan tambahan rinci-rinci yang memiliki fungsi tersendiri bagi anak - anak yang memakainya. Kerajinan gelang ini di kerjakan Bapak H. Hasan dalam kurung waktu sehari dengan di bantu satu orang karyawannya, menurut Bapak H. Hasan pengerjaan kerajinan gelang biasa cepat atau lama itu tergantung dari model dan ukuran perhiasan yang dikerjakannya.

5. Anting, Hasil kerajinan produk antinganting atau yang disebut perajin di Satando itu yaitu anting roda, adalah karya yang dibuat oleh perajin Bapak Anzar atau anggota kelompok Satando yang berbahan emas, yang masih dalam proses pengerjaan. Pengerjaan perhiasan cincin oleh perajin Bapak Anzar dengan mengunakan alat tradisional dan keterampilan tangan bisa memproduksi kerajinan perhiasan 20 pasang dengan estimasi waktu satu minggu untuk menjadi produk kerajinan yang siap untuk dijual.

6. Kalung, Hasil kerajinan kalung liontin, merupakan karya kerajinan Bapak Anwar yang merupakan anggota KPP Satando. Perhiasan ini adalah salah satu aksesoris wanita yang cukup digemari. Biasanya, wanita mempunyai lebih dari satu perhiasan.

Hasil karya produk kerajinan berupa kalung liontin emas yang merupakan perajin Bapak Atong dengan jenis kalung yang dibuat yaitu kalung emas untuk wanita. Bapak Atong hanya mengerjakan satu jenis kerajinan perhiasan saja yaitu kalung emas dan perak saja namun akhir akhir ini Bapak Atong lebih sering mengerjakan 
kalung emas dibandingkan dengan kalung perak dikarna kebutuhan atau pesanan.

\section{Ragam Hias Kerajinan Kelompok Satando}

Berdasarkan hasil survei, maka diperoleh data tentang jenis ragam hias pada hasil kerajinan atau produk perhiasan KPP Satando di Kecamatan Wajo, Kota Makassar sebagai berikut:

\section{a. Ragam Hias Flora}

Ragam hias yang disebut motif kembang pada kelompok perajin Satando yang dimana pada ragam hias ini banyak menggunakan motif daun bunga mawar yang dapat dilihat pada gambar sebagai berikut.

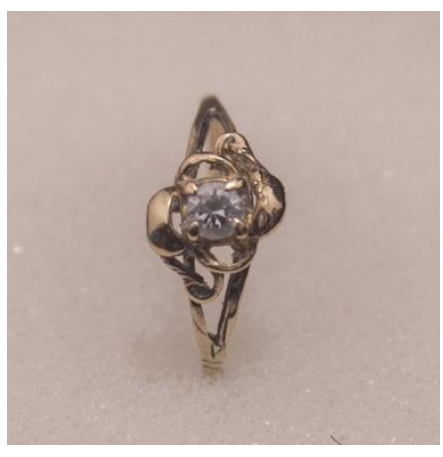

Gambar 1: Cincin Motif Ragam

Hias Tumbuhan

(Sumber:Muhammad Sanusi, Juli 2020)

Penggunaan motif pada karya produk kerajinan cincin pada gambar atas memiliki motif bunga (kembang) pada bagian atas cincin yang dipadukan pada bentuk daun yang mengelilingi batu permata pada bagian cincin tersebut, kemudian bagian bawah cincin tidak diberikan motif atau kesan polos.

Karya kerajinan produk cincin batu akik yang berbahan perak dengan motif flora yang mengelilingi batu permata. Dalam motif diatas perajinan menggunakan motif daun pada objek ragam hiasnya.

\section{b. Ragam Hias Geometris}

Ragam hias ini meliputi gasis lurus lengkung dan garis lingkaran pada motif ragam hias yang dikerjakan KPP Satando.

Hasil kerajinan Bapak Anzar yang me motif ragam hias geometris atau motif garis dan garis lingkaran dengan teknik pember menggunakan alat khusus yaitu kikir atau kikkiri.

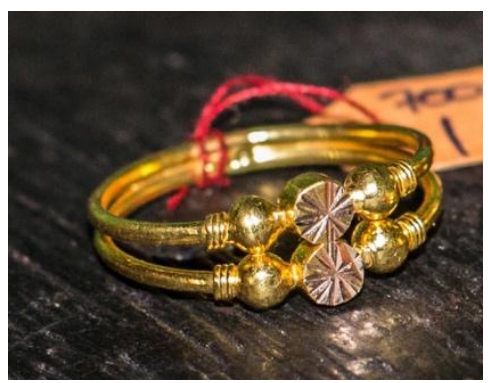

Gambar 2: Cincin Motif Ragam

Hias Geometris

(Sumber: Muhammad Sanusi, Juli 2020)

Sebelum ke pada tahap pembentukan motif pada kerajinan, tahapan yang dilakukan perajin di Satando yaitu membuat desain atau rancangan awal yang di tunjukan kepada konsumen atau pemilik perhiasan yang memesan pada perajin. Pada gambar nomor 24 menunjukan bahwa keterangan dan desain cincin yang akan dibuat dengan rincian bahan, berat atau kadar emas yang digunakan, bentuk jadi dengan tambahan ornamen pada cincin dan bahkan jadwal atau durasi pengerjaan di gambarkan secara lengkap dikertas tersebut.

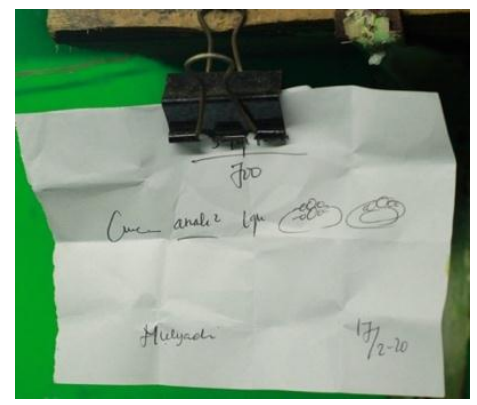

Gambar 3: Sketsa Desain

(Sumber: Muhammad Sanusi, Juli 2020)

Dengan adanya rancangan desain ini perajin sudah dapat mengetahui kerajinan yang akan dia kerjakan. Berikut ini disajikan data melalui tabel tentang penggunaan ragam hias pada anggota KPP Satando di Kota Makassar.

Melalui pembahasan di atas mengenai produk kerajinan perhiasan kelompok Satando di Kelurahan Malimongan Kecamatan Wajo Kota Makassar maka kita dapat mengukur sejauh mana apresiasi masyarakat, perajin dan penikmat seni terhadap pertumbuhan seni rupa di khususnya bidang kerajinan logam mulia di Makassar.

Sebagai salah satu Kota terbesar di Indonesia, Makassar telah mendapat predikat sebagai Kota dunia. Dikarenakan faktor letak geografisnya, tata bagunan serta ragam budayanya yang masih 
kental. Secara otomatis ketika telah berpredikat sebagai Kota Dunia maka dianggap kehidupan seni rupa dan industri di Kota Makassar juga telah berkembang.

Ketika membahas lebih dalam tentang seni rupa maka erat kaitannya dengan kerajinan. Meskipun terbentuknya pada Tahun 2015 yang lalu dengan inisiasi Pemerintah Kota Makassar dan Dinas Perindustrian kelompok KPP Satando yang sampai sekarang belum memiliki tempat produksi dan peralatan yang masih kurang, namun pertumbuhan kerajinan masih mampu menunjukkan eksistensinya. Sebagai bukti bahwa kerajinan yang berada Kelurahan Malimongan, kelompok Satando masih aktif berproduksi dengan jumlah anggota dan memiliki tempat kerja di rumah masing-masing dengan pembagian jenis produk kerajinan perhiasan yang dikerjakan dibagi disetiap anggota kelompok Satando. Yang dikerjakan di rumah masing-masing, dengan sumber daya ada dapat menghasilkan jenis produk kerajinan dalam seharinya. Selain itu kebutuhan masyarakat pada perhiasan seperti cincin, anting, dan gelang dan lain-lain. Masih di gemari dikalangan masyarakat baik itu masyarakat lokal maupun masyarakat diluar Kota Masyarakat.

Secara rinci pembahasan tentang produk dan ragam hias pada kerajinan Satando terutama di bagian produk KPP Satando hanya memproduksi perhiasan yang melekat pada tubuh misalnya perhiasan cincin, kalung, gelang dan anting-anting dengan bahan emas dan perak. Pada awal terbentuknya KPP Satando kehidupan perajin bisa di bilang cukup baik pada saat itu pemesanan selalu ada dan cukup banyak. Namun dengan berkembanganya jaman kelompok Satando mengalami penurunan di karnakan jumlah pemesanan berkurang di bandingan tahuntahun kemarin, hanya beberapa produk kerajinan yang masih banyak diminati dikalangan masyarakat yaitu produk cincin dan Kalung yang dimana pesanan atau peminat produk ini sangat dibutuhkan seperti mahar dalam pernikahan, atau hadiah kepada pasangan dan lain-lain. Produk kerajinan kelompok Satando pada awalnya hanya mengerjakan empat jenis kerajinan yang telah disebutkan di paragraf sebelumnya dan telah di bagi berdasarkan keahlian masing masing di setiap kelompok KPP Satando.

Selanjutnya pembahasan mengenai ragam hias pada kerajinan yang diterapkan oleh KPP Satando, dalam wawancara 27 Juli 2020 dengan narasumber Bapak H. Haris sebagai Ketua Kelompok Satando sekaligus Ketua RT di Satando 3 yang mengatakan bahwa ragam hias pada kerajinan yang dimilikinya rata-rata menggunakan motif garis dan kembang atau dengan kata lain ragam hias flora dan ragam hias geometris. Motif ragam hias flora dan geometris yang dikerjakan KPP Satando lebih kepada motif bunga, daun seperti bunga mawar, garis dan garis melengkung pada produk kerajinan pengerjaan motif tersebut disesuaikan permintaan konsumen atau pemesan yang ingin memakai motif tersebut. Ragam hias pada produk kerajinan perhiasan Bapak $\mathrm{H}$. Haris tidak menggunakan ragam hias figuratif dan fauna atau lainnya kecuali ragam hias flora dan geometris di karna minat dari konsumen dan pelanggan lebih dominan ke motif atau ragam hias flora dan geometris. Dikarnakan juga motif tersebut tidak terlalu sulit untuk dikerjakan dan alat yang digunakan juga masih tradisional. Berbeda juga dengan perajin Bapak Anzar perajin perhiasan cincin wanita yang merupakan anggota KPP Satando yang hanya mengunakan motif ragam hias geometris atau motif garis pada pengerjaan kerajinannya. Dari tinjauan di atas dapat di interprestasikan bahwa perkembangan kerajinan perhiasan di kelompok Satando di Kelurahan Malimongan, Kecamatan Wajo Kota Makassar masih perlu mendapatkan perhatian khusus dari segi pengembangan produk kerajinan dan referensi tentang ragam hias bagi perajin Satando sehingga produk kerajinan dapat bersaing di pasar lokal maupun di luar Kota Makassar.

\section{SIMPULAN DAN SARAN}

Berdasarkan hasil penelitian maka dapat ditarik kesimpulan sebagai berikut:

1. Hadirnya KKP Satando di Kelurahan Malimongan, Kecamatan Wajo, Kota Makassar merupakan salah satu alternatif di dalam memperkenalkan karya seni di bidang kerajinan logam mulia. Meskipun baru terbentuk sekitar lima tahun yang lalu namun kualitas karya yang ditampilkan mampu bersaing dengan karya-karya lain di Kota Makassar. Secara umum seni rupa di bidang kerajinan logam mulia Makassar mampu berkompetisi dapat dilihat dari sumber daya manusianya (perajin) dalam 
berkarya serta kreatifitas perajinnya. Hanya saja terkendala dibagian pengembangan produk dan jenis ragam hias yang masih digunakan pada awal terbentuknya KPP Satando.

2. Perkembangan produk kerajinan pada produk kerajinan Satando masih sama pada awal terbentuknya yang masih mengerjakan empat produk kerajinan perhiasan seperti cincin, gelang, kalung, dan anting-anting dengan bahan logam mulia emas dan perak. Sedangkan dengan ragam hias pada perhiasan Satando yang masing mengikuti permintaan konsumen dengan motif ragam hias flora dan ragam hias geometris.

3. Konsep-konsep kerajinan logam mulia atau kerajinan perhiasan di Kota Makassar sebagai Kota besar merupakan tugas para perajin untuk mengikuti zaman (trending) sebagai acuan untuk menambah pengetahuan dan referensi tentang perkembangan produk perhiasan dan jenis ragam hias dengan berbagai motif baik ragam hias flora dan geometris maupun ragam hias lainnya seperti fauna dan figuratif agar dapat di gunakan juga sebagai produk yang dapat bersaing dengan zaman yang sekarang ini dan para kelompok perajin-perajin yang ada di Kota Makassar untuk menarik perhatian konsumen lokal yang berada di Kota Makassar maupun konsumen berada di luar Kota Makassar.

Berdasarkan hasil tersebut maka penulis memberikan saran - saran sebagai berikut:

1. Fakultas Seni dan Desain Universitas Negeri Makassar, senantiasa terus meningkatkan jaringan kerja sama dibidang pengembangan kesenian (Seni Rupa dibidang kerajinan) dengan pihak pemerintah maupun pihak swasta yang ada di Kota Makassar maupun di Provinsi lainnya.

2. Kepada pemerintah Kota Makassar, memberikan wadah, satu tempat agar anggota perajin Satando dapat berkumpul di satu tempat untuk mengerjakan pesanan produk perhiasan, mengingat kebutuhan pasar akan karya seni seperti kerajinan logam mulia yang semakin berkembang dan mewujudkan Kota Industri

3. Kepada perajin-perajin kerajinan logam mulia berada di Kota Makassar agar lebih eksis lagi berusaha mengembangkan produk-produk kerajinan yang telah ada sebelumnya agar dapat dinikmati oleh masyarakat luas.

4. Kepada seluruh mahasiswa seni khususnya mahasiswa jurusan Seni Rupa dan Desain Komunikasi Visual untuk melakukan penelitian lanjut mengenai Kerajinan logam mulia di Kota Makassar.

\section{DAFTAR RUJUKAN}

Wahid, A. Kahar, Yunus, Pangeran Paita. 2014. Apresiasi Seni. Makassar: Prince Publishing.

Altheide, D. 1996. Qualitative Media AnalysisQualitative Research Methods. New York : Sage Publication

Barret, Terry. 1995. Criticizing Art. Toronto: Mayfield Publishing Company.

Departemen Pendidikan Indonesia. 2008. Kamus Besar Bahasa Indonesia. Jakarta: Balai Pustaka.

Sachari Agus. 2005. Pangantar Metodologi Penelitian Budaya Rupa. Jakarta: Penerbit Erlangga.

Sutanto Damid, dkk. 1984. Pengetahuan

Ornamen. U. Suryadi

Fieldman, Edmund Burke. 1967. Art as Image and Idea. New Jersey: Prentice-Hall, Inc.

Huberman, Miles B. Mathew. 1992. Analisis Data Kualitatif Buku Sumber Tentang Metode metode Baru. Jakarta: UIP

Kamus Besar Bahasa Indonesia, Edisi Kedua, Departemen Pendidikan dan 
Kebudayaan, Balai Pustaka, Jakarta, 1996, p. 881.

Rohendi Tjetjep. 2011. Metodologi Penelitian Seni. Semarang: Cipta Prima Nusantara.

Marianto, Dwi. M. 2002. Seni Kritik Seni. Yogyakarta: Lembaga Penelitian ISI Yogyakarta

Moleong Lexy. J. 2006. Metedologi Penelitian Kualitatif, Bandung: Remaja Rosda Karya.

Susanto Mikke. 2002. Diksi Rupa Kumpulan Istilah Seni Rupa. Yogyakarta: Penerbit Kanisius.

Ratna, Nyoman Kutha. 2010. Metodologi penelitian: Kajian Budaya dan Ilmu Sosial Humaniora Pada Umumnya. Yogyakarta: Pustaka Pelajar.

Sastra, Rantinah. 2018. Ragam Hias Nusantara. Klaten-Indonesia: PT. Intan Pariwara.

Sugiyono. 2009. Metode Penelitian Kuantitatif, Kualitatif dan R\&D. Bandung: Alfabeta. 2013. Metode Penelitian Kuantitatif, Kualitatif dan $R \& D$. Bandung: Alfabeta. 2003. Metode Penelitian Bisnis. Bandung: Cetakan Kelima: CV Alfabeta

Sukmadinata, N.S. 2011. Metode penelitian pendidikan. Bandung: Remaja Rosadakarya.

Soepratno, B. A. 1983. Ornamen Ukir Kayu Tradisonal Jawa. Semarang: Indonesia Australia Tehnical and Vocation Project IATVEPIA.

Toekio, Soegeng M. 1987. Mengenal Ragam Hias Indonesia. Bandung: Angkasa 